University of Nebraska - Lincoln

DigitalCommons@University of Nebraska - Lincoln

Faculty Papers and Publications in Animal

Science

Animal Science Department

1989

\title{
Muscle Protein Turnover and Tenderness in Broiler Chickens Fed Cimaterol
}

J. B. Morgan

University of Nebraska-Lincoln

Steven J. Jones

University of Nebraska-Lincoln, sjones1@unl.edu

Chris R. Calkins

University of Nebraska-Lincoln, ccalkins1@unl.edu

Follow this and additional works at: https://digitalcommons.unl.edu/animalscifacpub

Part of the Animal Sciences Commons

Morgan, J. B.; Jones, Steven J.; and Calkins, Chris R., "Muscle Protein Turnover and Tenderness in Broiler Chickens Fed Cimaterol" (1989). Faculty Papers and Publications in Animal Science. 577.

https://digitalcommons.unl.edu/animalscifacpub/577

This Article is brought to you for free and open access by the Animal Science Department at DigitalCommons@University of Nebraska - Lincoln. It has been accepted for inclusion in Faculty Papers and Publications in Animal Science by an authorized administrator of DigitalCommons@University of Nebraska - Lincoln. 


\title{
MUSCLE PROTEIN TURNOVER AND TENDERNESS IN BROILER CHICKENS FED CIMATEROL1,2,3
}

\author{
J. B. Morgan, S. J. Jones and C. R. Calkins \\ University of Nebraska ${ }^{4}$ \\ Lincoln 68583-0908
}

\begin{abstract}
To investigate the impact of cimaterol (CIM) on muscle protein tumover, carcass and muscle composition, muscle cathepsin $\mathrm{B}+\mathrm{L}$ activity and meat tenderness, 21-d-old broiler chickens $(n=88)$ were assigned to dietary treatments of either 0 or $1 \mathrm{ppm}$ CIM. Fractional synthesis rates (FSR), fractional accretion rates (FAR), proximate composition and collagen content were determined in the breast muscle (BM; pectoralis major) and a group of leg muscles (LM; gastrocnemius and peroneous longus) from groups of six birds per treatment within each of two time periods (age $=38$ or $56 \mathrm{~d}$ ). Whole body composition, serum hydroxyproline content and BM cathepsin $\mathrm{B}+\mathrm{L}$ activity also were measured. Fractional degradation rates (FDR) were calculated as the difference between FSR and FAR. Feeding CIM increased $(P<.01)$ whole body protein content. Weights of LM and percentage of body weight as BM and LM were increased $(P<.05)$ when CIM was included in the diet. Although FSR was natot significantly reduced by CIM feeding, it decreased $(P<.05)$ with increasing age. Due to decreases in FAR, FDR thereby was reduced by CIM $31.5 \%$ and $11.9 \%$ in BM and $38.2 \%$ and $37.4 \%$ in $\mathrm{LM}$ at $38 \mathrm{~d}$ and $56 \mathrm{~d}$ of age, respectively. Cathepsin $\mathrm{B}+\mathrm{L}$ activities also were reduced $33.6 \%(P<.01)$ and shear forces were increased by $41 \%(P<.05)$ by CIM feeding. For chickens fed CIM, the correlation between cathepsin $\mathrm{B}+\mathrm{L}$ activity and shear force was $-.63(P<.01)$. Feeding CIM improved carcass leanness and muscling due to reductions in FDR and proteolytic enzyme activity. Feeding CIM also reduced meat tendemess.
\end{abstract}

(Key Words: Cimaterol, Protein Synthesis, Degradation, Cathepsins, Tenderness.)

J. Anim. Sci. 1989. 67:2646-2654

\section{Introduction}

Skeletal muscle protein accretion occurs when the rate of protein synthesis exceeds the rate of protein breakdown. Attempts to study beta-agonist-induced muscle protein accretion have met with conflicting results. Many investigations have detected no effect of betaagonists on protein synthesis and suggest that

\footnotetext{
${ }^{1}$ Paper number 8771, Journal Series, Nebraska Agric. Res. Div., Inst. of Agric. and Nat. Resources.

${ }^{2}$ Cimaterol provided as a gift from American Cyanamid, Princeton, NJ.

${ }^{3}$ This research was supported by the Univ. of NebraskaLincoln Res. Council and NIH Biomed. Res. Support Grant RR-07055.

${ }^{4}$ Dept. of Anim. Sci.

Received October 20, 1988.

Accepted March 7, 1989.
}

increased muscle hypertrophy is due to a decrease of protein degradation (MacRae et al., 1986; Reeds et al., 1986). However, Emery et al. (1984) and Deschaies et al. (1981) have reported that clenbuterol increased muscle hypertrophy in rats by stimulating protein synthesis. Bergen et al. (1987) observed that skeletal muscle protein synthesis was increased in pigs treated with the beta-adrenergic agonist ractopamine.

Changes in muscle protein turnover by addition of beta-agonists to the diet may improve not only the efficiency of lean tissue growth but also may influence the activity of proteolytic enzymes, which may affect meat tenderness. Several protease systems within muscle could contribute to tendemess. Cadependent proteases (CDP) require $\mathrm{Ca}^{++}$and have a neutral $\mathrm{pH}$ optimum for activity (Koohmaraie et al., 1986). Wang et al. (1988) 
reported that lambs fed cimaterol (CIM) for 3 or 6 wk displayed shear force values $14.5 \%$ and $44.1 \%$ greater than controls, respectively. Additionally, dietary administration of CIM reduced micromolar-CDP activity by 55 to $70 \%$ in longissimus muscle. Secondly, lysosomes, which contain high concentrations of proteolytic enzymes (primarily cathepsins), have long been assumed to be a major site for protein degradation in mammalian cells (Trenkle, 1986). Catheptic enzymes have activity toward muscle protein such as myosin, troponin and tropomyosin (Ouali et al., 1987). Forsberg et al. (1987) reported that sheep fed a diet containing cimaterol had muscle cathepsin B activity values that were $45 \%$ lower than controls. Calkins and Seideman (1988) reported that both CDP and cathepsin B enhance tenderness. Evidence that the lysosomal proteinases are involved in meat tenderness also has been provided by Ouali et al. (1987). Depression of the activity of these enzymes by feeding of beta-agonists may reduce meat tenderness.

The benefits of beta-agonists on improving carcass leanness are well-documented; however, knowledge of the mechanisms by which CIM influences protein turnover is still incomplete. This is particularly apparent in broiler chickens that have been intensively, genetically selected for rapid muscle growth. Use of chickens as a model also provides an opportunity to determine differences in response of muscle types to CIM. The objective of this investigation was to understand the effect of CIM on protein turnover, carcass and muscle composition, lysosomal enzyme activity and meat tenderness in broiler chickens.

\section{Experimental Procedure}

Animals and Design. Eighty-eight broiler chickens were obtained at $1 \mathrm{~d}$ of age, wingbanded, weighed and housed in electrically heated starting batteries 5 with raised wire floors in a room lighted $24 \mathrm{~h} / \mathrm{d}$ and maintained at a temperature of $23^{\circ} \mathrm{C}$. Birds were given tap water and ad libitum access to a standard sorghum-soybean broiler starter diet $(23 \% \mathrm{CP}$; $3,108 \mathrm{kcal} \mathrm{ME} / \mathrm{kg}$ ) containing corn $(52.5 \%)$

\footnotetext{
${ }^{5}$ Petersime Incubator $\mathrm{Co}$, Gettysburg, $\mathrm{OH}$.

${ }^{6}$ Amersham/Searle, Des Plaines, IL.
}

soybean meal (31.2\%; $47.5 \%$ protein), DLmethione $(.05 \%)$ and vitamin and mineral premix. On d 21 , chicks were randomly assigned to the above diet containing 0 or 1 ppm cimaterol (CON or CIM, respectively) and placed in unheated growing batteries (70 $\mathrm{cm} \times 80 \mathrm{~cm}$; six birds per cage).

Fractional Synthesis Rates. Skeletal muscle fractional synthesis rates (FSR \%/d) were measured using the methods of Kang et al. (1985) on six birds from each treatment at 38 and $56 \mathrm{~d}$. An emulsion of $\mathrm{L}-\left(\mathrm{U}-{ }^{14} \mathrm{C}\right)$ tyrosine $(495 \mathrm{mCi} / \mathrm{mmol})^{6}$ and sesame oil $(1 \mu \mathrm{Ci} / \mathrm{ml} ; .4$ $\mathrm{ml} / 100 \mathrm{~g}$ body weight) was injected subcutaneously along the back using a 16-gauge needle. The injected chickens were placed in individual metabolism chambers that consisted of an 18-liter glass jar and a plexiglass lid with air exchanged at a rate of approximately 6 liters per min. The expired air was trapped in $15 \mathrm{ml}$ of a trapping solution of one part ethanolamine and two parts ethylene glycol monoethyl ether (methyl cellosolve; $\mathrm{v} / \mathrm{v}$ ). The solution was changed every $15 \mathrm{~min}$ during the 90-min postinjection period. Radioactivity in the expired $\mathrm{CO}_{2}$ was measured to assure that a steady state was obtained. The collection of $\mathrm{CO}_{2}$ to determine a steady state of radioactive tyrosine was validated in a previous study (Jones et al., 1986). All chicks attained a plateau in ${ }^{14} \mathrm{CO}_{2}$ expiration within $1 \mathrm{~h}$.

At $90 \mathrm{~min}$, chickens were removed from metabolism chambers and killed by cervical dislocation. The breast muscle (pectoralis major, BM) and a group of leg muscles (gastrocnemius and peroneous longus; LM) were removed immediately, frozen in liquid nitrogen and stored at $-20^{\circ} \mathrm{C}$. The bound and free amino acid pools were separated by precipitation of the proteins using 5\% trichloroacetic acid and centrifugation of the sample at $1,500 \times g$. Specific radioactivities of bound (pellet) and free (supernatant fluid) tyrosine were determined using the procedures of Jones et al. (1986). Protein content of the individual muscles was determined by homogenizing a sample of the muscle in $3 \mathrm{M} \mathrm{NaOH}$ and using the Biuret method of Gomall et al. (1949). DNA was analyzed using the method of Labraca and Paigen (1980). RNA was separated using the method of Shiboko et al. (1967) and quantitated using the methods of Lin and Schjeide (1969).

Fractional Accretion Rates and Composition. Five chickens from the 0 and $1 \mathrm{ppm}$ 
groups were killed $3 \mathrm{~d}$ before and $3 \mathrm{~d}$ after injection with isotope to measure fractional accretion rates (FAR; \%/d) at each time period. Muscles were weighed and protein content was determined using the method mentioned above. Regression of total muscle protein on age was used to estimate FAR. Fractional degradation rates (FDR, \%/d) were determined by the differences between FAR and FSR. To determine carcass composition, fat, protein and moisture were measured in the BM, LM and whole body using AOAC (1985) procedures.

Proteinase Activities and Hydroxyproline Analyses. Six birds from each treatment were bled via cardiac puncture then were killed at $38 \mathrm{~d}$ or $56 \mathrm{~d}$ of age and one side of the BM was removed immediately, frozen in liquid nitrogen and stored at $-100^{\circ} \mathrm{C}$ until analyzed for cathepsin $\mathrm{B}+\mathrm{L}$ activity. The other side of the $B M$ remained in the carcass for $2 \mathrm{~h}$ at room temperature and then was removed and chilled for $24 \mathrm{~h}$ at $7^{\circ} \mathrm{C}$ before being frozen $\left(-100^{\circ} \mathrm{C}\right)$ and stored for tenderness evaluation. Serum was frozen until analyzed for serum hydroxyproline using the procedures of Bergman and Loxley (1963).

Cathepsin $\mathrm{B}+\mathrm{L}$ activities were determined on samples prepared using the procedures of Moeller et al. (1976) in which $10 \mathrm{~g}$ of finely minced, pre-rigor muscle was homogenized in $40 \mathrm{ml}$ of $.02 \mathrm{M} \mathrm{KCl}$ containing $.25 \mathrm{M}$ sucrose. Homogenates were filtered through cheesecloth and adjusted to a pH above 7.3 using $1 \mathrm{~N}$ $\mathrm{KOH}$. The homogenates then were centrifuged at $5,000 \times g$ for $5 \mathrm{~min}$. Supernatant fluids were retained and the resulting pellet was resuspended in $35 \mathrm{ml}$ of the $\mathrm{KCl} /$ sucrose solution. The $\mathrm{pH}$ adjustment and centrifugation were repeated and the supernatant fractions were pooled for determination of cathepsin $\mathrm{B}+\mathrm{L}$ activity. Except for the omission of an ultracentrifugation step to separate bound and unbound enzyme fractions, these procedures mimic those of Moeller et al. (1976).

Activities of cathepsin $\mathrm{B}+\mathrm{L}$ were determined using the techniques of Barrett (1980) with N-CBZ-L-phenylalanyl-L-arginine 7amido-4-methylcoumarin, which is recognized to be hydrolyzed by both cathepsin $B$ and $L$

\footnotetext{
${ }^{7}$ Omega Engineering Inc., Stamford, CT.

8 Instron Inc., Canton, MA.
}

(Etherington et al., 1987). The total activities of cathepsins $B+L$ were adjusted to reflect total units of activity in $10 \mathrm{~g}$ of muscle.

The BM muscles used to determine tenderness were thawed at $7^{\circ} \mathrm{C}$ for $24 \mathrm{~h}$. Muscles were individually wrapped in aluminum foil, placed on roasting racks and cooked to an internal temperature of $82^{\circ} \mathrm{C}$ in a gas oven. Internal temperature was monitored using small-diameter copper-constantan thermocouples attached to an Omega digital thermometer 7 . Cooked BM were cooled to room temperature and held for shear force evaluation later the same day. Duplicate samples $(1 \times 1 \times$ 2 to $3 \mathrm{~cm}$ ) were removed from the anterior third of each cooked muscle. Samples were sheared in a direction perpendicular to muscle fibers using an Instron Universal Testing Machine ${ }^{8}$ with a Warner-Bratzler shear attachment. Four values from each BM were averaged to obtain a shear force value for each muscle.

Muscle hydroxyproline content was determined in triplicate on samples of the BM and LM of birds used to measure FSR. Samples were prepared using the methods of Hill (1966) to separate soluble and insoluble collagen. The procedures of Bergman and Loxley (1963) were used to spectrophotometrically determine hydroxyproline content. Hydroxyproline concentration was converted to collagen content using conversion factors of 7.52 (Cross et al., 1973) and 7.25 (Goll et al., 1963) for the soluble and insoluble fractions, respectively. Total collagen content was defined as the sum of the soluble and insoluble fractions.

Statistics. Statistical treatment of data involved an analysis of variance using a model with diet and age as two factors in a factorial experiment (Steel and Torrie, 1980). Treatment means, standard deviations and analysis of variance were calculated and performed using SAS (Barr et al., 1976). Significant interactions between age and dietary treatment were evaluated by the least significant difference technique, utilizing a modified $t$-statistic to allow for comparison of diet effects within age (Steel and Torrie, 1980).

\section{Results and Discussion}

No differences were detected between body weights of chickens fed 0 and 1 ppm CIM within different age periods (Table 1), but CIM 
TABLE 1. EFFECT OF CIMATEROL ON BODY AND MUSCLE WEIGHTS OF 38- AND 56-DAY-OLD BROILER CHICKS

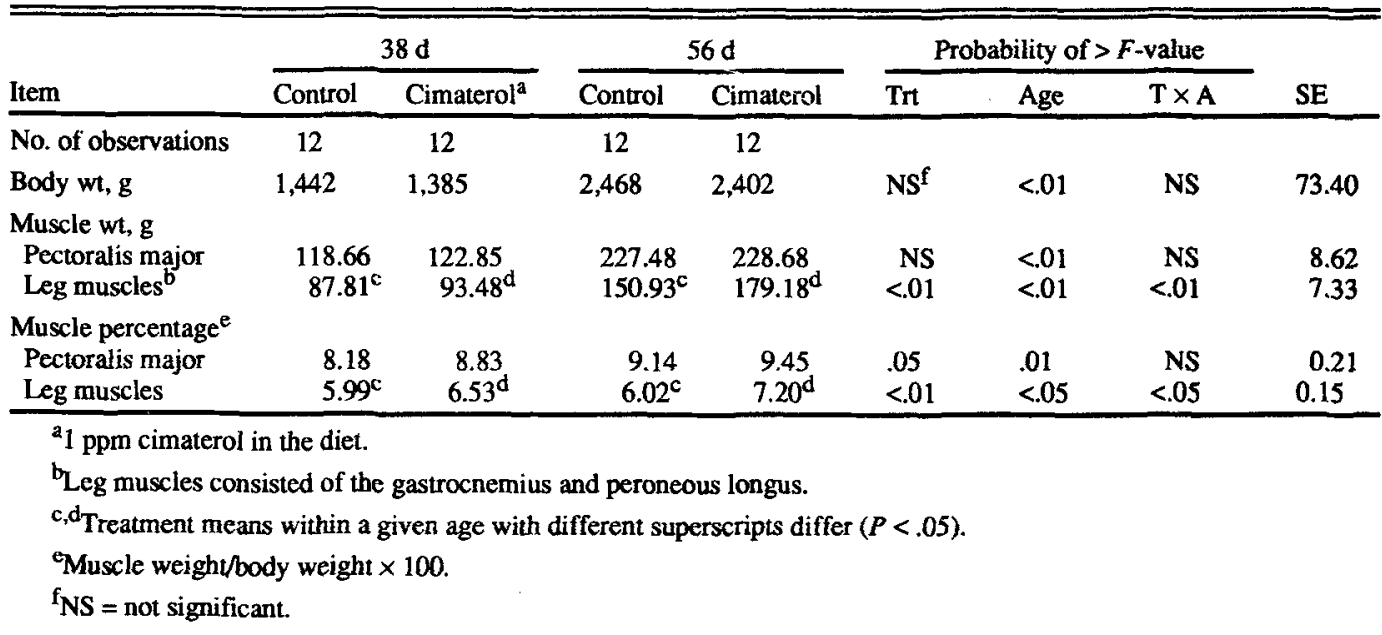

birds tended to have slightly lighter body weights than CON birds. Animals fed $1 \mathrm{ppm}$ CIM for 38 and $56 \mathrm{~d}$ had 7.37 and $3.28 \%$ heavier $(P<.05)$ BM compared with CON animals (Table 1). Significant age $\times$ treatment interactions were observed for LM weight and LM as a percentage of the whole body. The magnitude of difference in LM weight and percentages between $\mathrm{CON}$ and CIM was greater at $56 \mathrm{~d}$ than at $38 \mathrm{~d}(18.7 \%$ and $19.6 \%$, respectively).

Chickens fed CIM had higher $(P<.01)$ percentages of whole body protein than did controls (Table 2). Whole body fat and moisture percentages exhibited a significant $(P$ $<.01)$ treatment $\times$ age interaction. Differences in fat and moisture was not manifested until the latter stages of the growing period (d 56), at which time CIM-treated chickens had $4.57 \%$ more body moisture and $19.9 \%$ less body fat than did 56-d CON chickens $(P<.05)$. Apparently, long-term administration of CIM is needed before whole body fat is reduced significantly. Leg muscles from CIM-fed birds were lower $(P<.05)$ in percentage fat and higher $(P<.05)$ in percentage protein than LM from control birds. However, no differences were detected in BM composition, regardless of dietary treatment or age. Watson-Wright and Wilkinson (1986) reported that skeletal muscle possesses receptors of the beta- 2 subclass, but that receptor density is a function of muscle type. White fibers appear to have a low beta receptor density, whereas red fibers contain a high beta receptor density. The lack of response in BM to CIM treatment could be due partially to the high proportion of white fibers in $B M$ relative to $L M$.

No treatment differences in FSR were observed in either muscle type, although BM and LM from CIM-fed animals displayed numerically lower FSR compared with controls (Table 3). The FSR or BM $(P<.01)$ and LM $(P<.05)$ decreased rapidly with increasing age of birds. Maruyama et al. (1978) and McDonald and Swick (1981) also noted a rapid age-related decline in FSR in chickens. Similar trends were observed for rats (Millward et al., 1978; Bates and Millward, 1981).

Fractional degradation rates were calculated as the difference between fractional accretion rate and FSR. Calculated FDR values for birds fed CIM were depressed $31.48 \%$ and $11.91 \%$ for $\mathrm{BM}$ and $38.16 \%$ and $37.36 \%$ for $\mathrm{LM}$ at 38 $\mathrm{d}$ and $56 \mathrm{~d}$ of age, respectively. Therefore, it can be assumed that CIM increased muscle hypertrophy by lowering FDR values. Research by Reeds et al. (1986) reported that clenbuterol had no effect on muscle protein FSR and suggested a rapid and perhaps direct, inhibitory effect on protein FDR.

No differences $(P>.05)$ were observed in RNA concentration or protein:RNA ratios in muscles from different treatment groups at 38 d or $56 \mathrm{~d}$ of age (Table 4). An age difference was exhibited in RNA activity for BM $(P<$ $.01)$ and LM $(P<.05)$. The decrease in RNA activity associated with increasing age is associated with the decrease of FSR at $38 \mathrm{~d}$ compared with $56 \mathrm{~d}$ of age (Table 3). Millward 
TABLE 2. EFFECT OF CIMATEROL ON WHOLE BODY AND MUSCLE PROXIMATE COMPOSITION OF 38-AND 56-DAY-OLD BROILER CHICKS

\begin{tabular}{|c|c|c|c|c|c|c|c|c|}
\hline \multirow[b]{2}{*}{ Item } & \multicolumn{2}{|c|}{$38 \mathrm{~d}$} & \multicolumn{2}{|c|}{$56 \mathrm{~d}$} & \multicolumn{3}{|c|}{ Probability of $>F$-value } & \multirow[b]{2}{*}{ SE } \\
\hline & Control & Cimaterol $^{\mathbf{a}}$ & Control & Cimaterol & Trt & Age & $\mathbf{T} \times \mathbf{A}$ & \\
\hline No. of observations & 10 & 10 & 10 & 10 & & & & \\
\hline $\begin{array}{l}\text { Whole body, \% } \\
\text { Moisture } \\
\text { Fat } \\
\text { Protein }\end{array}$ & $\begin{array}{l}63.96 \\
15.23 \\
17.60\end{array}$ & $\begin{array}{l}63.18 \\
15.12 \\
18.65\end{array}$ & $\begin{array}{l}60.63^{b} \\
18.31^{b} \\
18.42\end{array}$ & $\begin{array}{l}63.53^{\mathrm{c}} \\
14.66^{\mathrm{c}} \\
19.45\end{array}$ & $\begin{array}{l}N^{\mathrm{e}} \\
<.10 \\
<.01\end{array}$ & $\begin{array}{r}\text { NS } \\
\text { NS } \\
<.10\end{array}$ & $\begin{array}{r}<.05 \\
<.01 \\
\text { NS }\end{array}$ & $\begin{array}{r}.81 \\
1.01 \\
.36\end{array}$ \\
\hline $\begin{array}{l}\text { Pectoralis major, \% } \\
\text { Moisture } \\
\text { Fat } \\
\text { Protein }\end{array}$ & $\begin{array}{r}74.54 \\
.91 \\
24.51\end{array}$ & $\begin{array}{r}74.54 \\
1.03 \\
25.01\end{array}$ & $\begin{array}{r}74.34 \\
.93 \\
25.08\end{array}$ & $\begin{array}{r}74.43 \\
1.11 \\
24.98\end{array}$ & $\begin{array}{l}\text { NS } \\
\text { NS } \\
\text { NS }\end{array}$ & $\begin{array}{l}\text { NS } \\
\text { NS } \\
\text { NS }\end{array}$ & $\begin{array}{l}\text { NS } \\
\text { NS } \\
\text { NS }\end{array}$ & $\begin{array}{l}.24 \\
.17 \\
.26\end{array}$ \\
\hline $\begin{array}{l}\text { Leg muscles }^{\mathrm{d}}, \% \\
\text { Moisture } \\
\text { Fat } \\
\text { Protein }\end{array}$ & $\begin{array}{r}76.55 \\
3.69 \\
20.64\end{array}$ & $\begin{array}{r}76.38 \\
3.04 \\
21.37\end{array}$ & $\begin{array}{r}76.00 \\
3.67 \\
20.70\end{array}$ & $\begin{array}{r}75.84 \\
3.24 \\
21.33\end{array}$ & $\begin{array}{r}\text { NS } \\
<.05 \\
<.05\end{array}$ & $\begin{array}{l}\text { NS } \\
\text { NS } \\
\text { NS }\end{array}$ & $\begin{array}{l}\text { NS } \\
\text { NS } \\
\text { NS }\end{array}$ & $\begin{array}{c}.26 \\
.22 \\
.17\end{array}$ \\
\hline
\end{tabular}

${ }^{2} 1 \mathrm{ppm}$ cimaterol in the diet.

b,c Treatment means within a given age with different superscripts differ $(P<.05)$.

Leg muscles consisted of the gastrocnemius and peroneous longus.

$\mathbf{e}_{\mathrm{NS}}=$ not significant.

et al. (1975) reported that growing rats exhibited a more rapid decline in FSR than could be attributed to dilution of RNA within the muscle. They concluded that to maintain a high FSR, FDR also must be high to prevent RNA dilution by rapid protein accumulation.

Muscle DNA concentrations were greater in
LM than in BM at both $38 \mathrm{~d}$ and $56 \mathrm{~d}$ of age (Table 4). Differences in DNA between muscles may relate to differing populations of fibroblasts, adipocytes and other non-muscle cells in the BM and LM. No treatment effects on DNA concentrations were detected in BM or LM (Table 4). Beerman et al. (1985)

TABLE 3. EFFECT OF CIMATEROL ON FRACTIONAL SYNTHESIS, DEGRADATION AND ACCRETION IN MUSCLE OF 38-AND 56-DAY-OLD BROILER CHICKS

\begin{tabular}{|c|c|c|c|c|c|c|c|c|}
\hline \multirow[b]{2}{*}{ Item } & \multicolumn{2}{|c|}{$38 \mathrm{~d}$} & \multicolumn{2}{|c|}{$56 \mathrm{~d}$} & \multicolumn{3}{|c|}{ Probability of $>F$-value } & \multirow[b]{2}{*}{ SE } \\
\hline & Control & Cimaterol $^{\mathbf{a}}$ & Control & Cimaterol & $\overline{\operatorname{Trt}}$ & Age & $T \times A$ & \\
\hline \multicolumn{9}{|l|}{$\begin{array}{l}\text { Fractional synthesis }{ }^{b} \\
\text { rate, \%/d }\end{array}$} \\
\hline $\begin{array}{l}\text { Pectoralis muscle } \\
\text { Leg muscles }\end{array}$ & $\begin{array}{l}15.64 \\
15.99\end{array}$ & $\begin{array}{l}14.11 \\
13.44\end{array}$ & $\begin{array}{l}9.58 \\
9.29\end{array}$ & $\begin{array}{l}7.68 \\
8.65\end{array}$ & $\begin{array}{l}\mathrm{NS}^{\mathrm{e}} \\
\mathrm{NS}\end{array}$ & $\begin{array}{l}<.01 \\
<.05\end{array}$ & $\begin{array}{l}\text { NS } \\
\text { NS }\end{array}$ & $\begin{array}{l}1.66 \\
1.57\end{array}$ \\
\hline \multicolumn{9}{|c|}{$\begin{array}{l}\text { Fractional degradation } \\
\text { rate, } \% / d\end{array}$} \\
\hline $\begin{array}{l}\text { Pectoralis major } \\
\text { Leg muscles }\end{array}$ & $\begin{array}{l}11.69 \\
10.09\end{array}$ & $\begin{array}{l}8.01 \\
6.24\end{array}$ & $\begin{array}{l}5.88 \\
4.39\end{array}$ & $\begin{array}{l}5.18 \\
2.75\end{array}$ & & & $\begin{array}{l}\mathbf{N A}^{\mathbf{e}} \\
\mathbf{N A}\end{array}$ & \\
\hline \multicolumn{9}{|l|}{$\begin{array}{l}\text { Fractional accretion } \\
\text { rate }^{\mathrm{d}}, \% / \mathrm{d}\end{array}$} \\
\hline $\begin{array}{l}\text { Pectoralis major } \\
\text { Leg muscles }\end{array}$ & $\begin{array}{l}3.95 \\
5.90\end{array}$ & $\begin{array}{l}6.10 \\
7.20\end{array}$ & $\begin{array}{l}3.70 \\
4.90\end{array}$ & $\begin{array}{l}2.50 \\
5.90\end{array}$ & & & $\begin{array}{l}\mathbf{N A} \\
\mathbf{N A}\end{array}$ & \\
\hline
\end{tabular}

${ }^{\mathrm{a}} 1 \mathrm{ppm}$ cimaterol in the diet.

${ }^{b}$ Number of observations per treatment equals six.

${ }^{c_{L}}$ eg muscles consisted of the gastrocnemius and peroneous longus.

${ }^{\mathrm{d}}$ Calculated by linear regression from data of subgroups of birds sacrificed $3 \mathrm{~d}$ before and $3 \mathrm{~d}$ after infusion stuides $(n=5$ per subgroup per treatment).

eNS = not significant; NA = not determined. 
TABLE 4. EFFECT OF CIMATEROL ON RIBONUCLEIC ACID AND DEOXYRIBONUCLEIC ACID IN MUSCLE OF 38- AND 56-DAY-OLD BROILER CHICKS

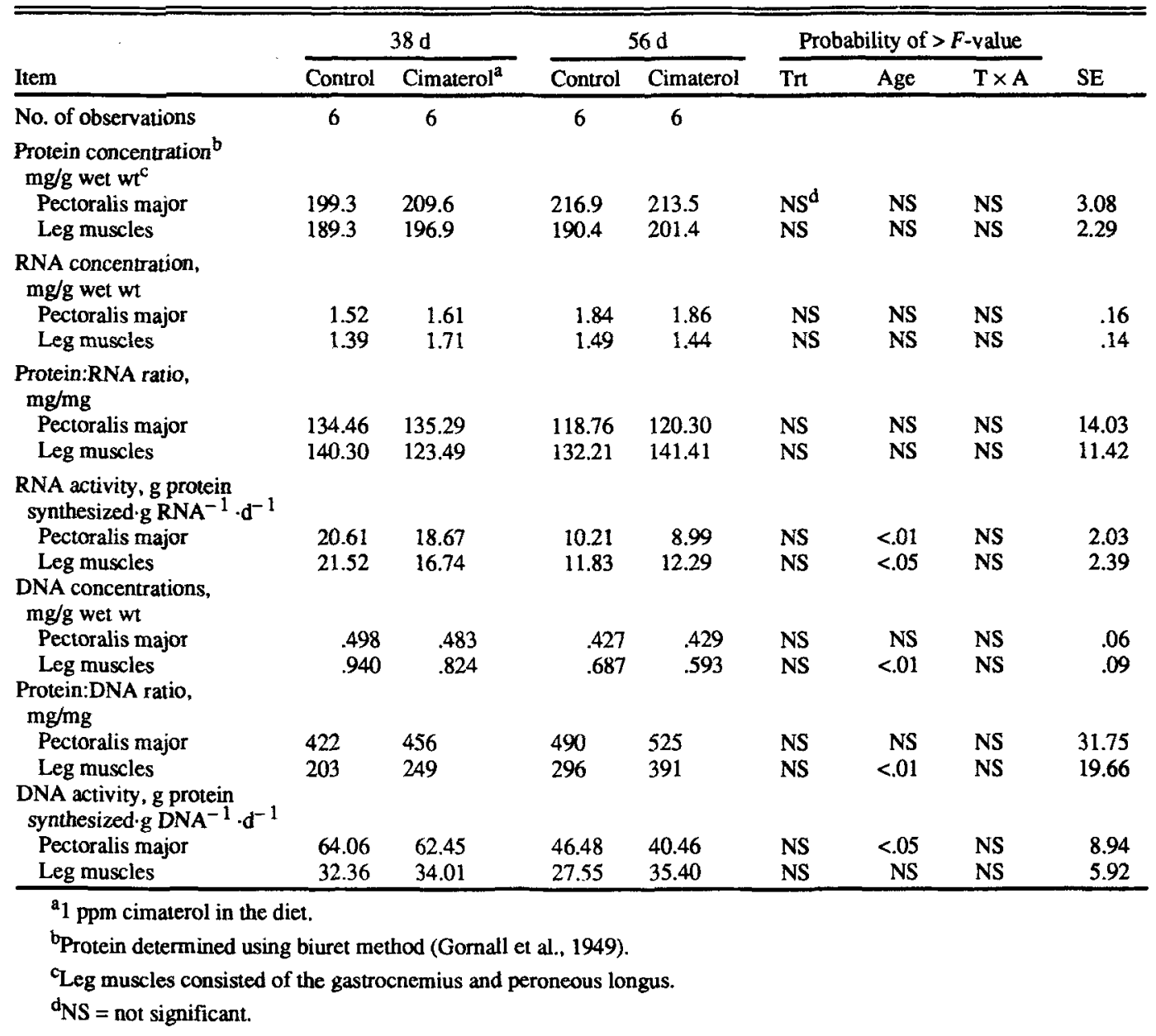

reported a lower concentration of DNA at 7 wk in CIM-fed lambs, although at 12 wk there were no differences between CON and CIMtreated lambs. The reason no differences were detected in the present study may be because the transient changes evident in lambs early in feeding may have occurred already in chickens before DNA measurements were made. Concentration of DNA was lower $(P<.01)$ in LM at $56 \mathrm{~d}$ than at $38 \mathrm{~d}$ of age (Table 4). This change is due partly to the dilution of DNA by muscle protein being accreted.

Postnatal muscle growth is caused primarily by cellular hypertrophy. The ratio of protein to DNA is an indication of physiological cell size (i.e., the quantity of cytoplasm supported by a single nucleus). Although not significant, protein:DNA ratios in BM and LM tended to be higher in CIM-fed birds than in the controls at both age periods. However, protein:DNA ratios in LM were higher $(P<.01)$ at $56 \mathrm{~d}$ than at $38 \mathrm{~d}$ of age (Table 4). These data support the concept of lower protein degradation rates in the LM.

Because no differences were detected in DNA concentration, increased muscle mass does not appear to be attributable to increased satellite cell division followed by fusion to existent muscle fibers. This is supported by work by Kim et al. (1987), who found the DNA concentration per unit of muscle or per unit of protein was lower in CIM-fed lambs than in the control group. These results suggest that the increase of DNA is not a prerequisite for beta-agonist-induced hypertrophy of muscle.

To assess the relationship of changes in protein turnover to changes in muscle protein 
TABLE 5. EFFECT OF CIMATEROL ON CATHEPSIN B+L ACTIVITY, SHEAR FORCE, SERUM HYDROXYPROLINE AND MUSCLE COLLAGEN CONTENT OF 38- AND 56-DAY-OLD BROILER CHICKS

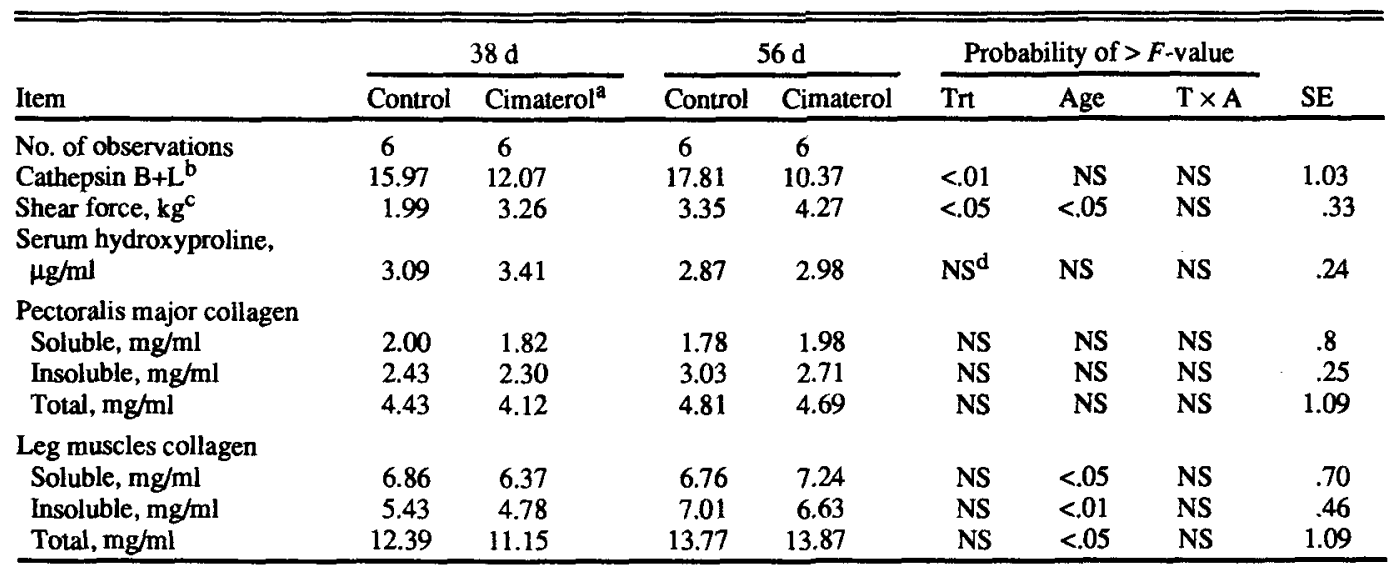

${ }^{a} 1 \mathrm{ppm}$ cimaterol in the diet.

botal activity, $\mathrm{nmol} /(\mathrm{min} \cdot 10 \mathrm{~g}$ wet muscle), determined in the pectoralis major.

'Shear value determined from slices $(1 \times 1 \times 2$ to $3 \mathrm{~cm})$ taken from the anterior third portion of the cooked pectoralis major.

dNS = not significant.

mass, rates of protein synthesis also were expressed per gram of DNA (DNA activity). In LM, no differences were observed in DNA activity at any age, whereas DNA activity was lower $(P<.05)$ in BM at $56 \mathrm{~d}$ than at $38 \mathrm{~d}$ of age.

Shear force values of BM from CIM-fed animals were $39.0 \%$ and $21.6 \%$ higher than those from controls at 38 and $56 \mathrm{~d}$, respectively (Table 5). These results are in agreement with Hamby et al. (1986), who reported that Warner-Bratzler shear values of cooked longissimus muscle from clenbuterol-fed sheep were higher than values of samples from control lambs. Jones et al. (1985) noted that $1 \mathrm{ppm}$ of CIM increased meat toughness in pigs.

Bird et al. (1978) have demonstrated that several cathepsins are capable of degrading stromal and contractile proteins. Cathepsin $\mathrm{B}+\mathrm{L}$ activities were lower $(P<.01)$ in muscles from CIM-fed birds than in muscles from controls (Table 5). Cathepsin $\mathrm{B}+\mathrm{L}$ activities from birds fed CIM were $24.4 \%$ and $41.8 \%$ lower than those from control birds at 38 and $56 \mathrm{~d}$, respectively. The depressed FDR observed in CIM-fed animals may be the result of lower proteolytic capacity from catheptic enzymes. If endogenous catheptic enzymes are related both to protein turnover in living muscle and to tenderization postmortem, then an increase in the amount of catheptic enzymes during growth would be expected to enhance meat tenderness (Calkins et al., 1987). Kretchmar et al. (1988) reported decreased cathepsin B activity values in muscles of sheep fed the beta-agonist L-644,969. Simple comelation coefficients between cathepsin $B+L$ activities and shear force values within birds fed CIM were calculated. The negative correlation $(r=-.63 ; P<.05)$ between cathepsin $B+L$ and shear force values from birds fed CIM indicates that birds with lower amounts of cathepsin $\mathrm{B}+\mathrm{L}$ activity were less tender. Birds fed CIM exhibited low cathepsin B+L activity values and increased muscle toughness compared with muscle from control birds. However, cathepsin $\mathrm{B}+\mathrm{L}$ activities from $\mathrm{BM}$ of control birds were not related $(r=.48 ; P<.10)$ to increased tenderness ratings, mostly due to four extreme outliers at $56 \mathrm{~d}$ of age.

No differences were observed in serum hydroxyproline, an index of the rate of collagen turnover, between animals fed a CIM or CON diet (Table 5). Similar methods of estimating collagen turnover were used by $\mathrm{Wu}$ et al. (1981). Animals displayed slightly higher $(P>.05)$ concentrations of serum hydroxyproline at $38 \mathrm{~d}$ of age than at $56 \mathrm{~d}$ of age, reflecting the dynamic nature of collagen turnover and suggesting the presence of immature collagen containing fewer insoluble crosslinks. No treatment or age-related differ- 
ences $(P>.10)$ were observed in soluble, insoluble or total collagen levels within BM. The LM from animals $56 \mathrm{~d}$ of age contained significantly greater amounts of soluble, insoluble and total collagen than did that of 38-d-old birds.

Results of this study suggest that feeding CIM to broiler chicks increases muscle protein mass by retarding protein degradation. These changes may be reflected in the depressed catheptic activity values noted in CIM-treated birds. Muscle from CIM-treated birds displayed increased toughness, possibly due to lower catheptic proteinase capacity. Reductions in cathepsin $B+L$ activity in muscle could contribute to the CIM-induced muscle hypertrophy.

\section{Literature Cited}

AOAC. 1985. Official Methods of Analysis (14th Ed.). Association of Official Analytical Chemists, Washington, DC.

Barr, A. J, J. H. Goodnight, J. P. Sall and J. T. Helwig. 1976. A Users Guide to SAS 76. Sparks Press, Raleigh, NC

Barrett, A. J. 1980. Fluorometric assays for cathepsin B and cathepsin $\mathrm{H}$ with methylcoumarylamide substrates. Biochem. J. 187:909.

Bates, P. C. and D. J. Millward. 1981. Characteristics of skeletal muscle growth and protein turnover in a fast growing rat strain. Br. J. Nutr. 46:7.

Beerman, D. H., D. R. Campion and R. H. Dalrymple. 1985. Mechanisms responsible for partitioning tissue growth in meat animals. Proc. Recip. Meat Conf. 38:105.

Bergen, W. G., S. E. Johnson, D. M. Skjaerlund, R. A. Merkel and D. B. Anderson. 1987. The effect of ractopamine on skeletal muscle metabolism in pigs. Fed. Proc. 46:1021 (Abstr. \#4105).

Bergman, I. and R. Loxley. 1963. Two improved and simplified methods for the spectrophotometric determination of hydroxyproline. Anal. Chem. 35:1961.

Bird, J.W.C., A. M. Spanier and W. N. Schwartz. 1978. Cathepsin $B$ and D activity and ultrastructural location in skeletal muscle. In: H. L. Segal and D. J. Doyle (Ed.) Protein Turnover and Lysosome Function. Academic Press, New York.

Calkins, C. R. and S. C. Seideman. 1988. Relationships among calcium-dependent protease, cathepsin $\mathrm{B}$ and $\mathrm{H}$, meat tenderness and the response of muscle to aging. J. Anim. Sci. 66:1186.

Calkins, C. R., S. C. Seideman and J. D. Crouse. 1987. Relationships between rate of growth, catheptic enzymes and meat palatability in young bulls. J. Anim. Sci. 64:1448.

Cross, H. R., Z. L. Carpenter and G. C. Smith. 1973. Effects of intramuscular collagen and elastin on bovine muscle tenderness. J. Food Sci. 39:998.

Deschaies, Y., J. Willemot and J. Leblanc. 1981. Protein synthesis, amino acid uptake and pools during isoproterenol-induced hypertrophy of the rat heart and tibialis muscle. Can J. Physiol. Pharmacol. 59:113.

Emery, P. W., N. J. Rothwell, M. J. Stock and P. D. Winter. 1984. Chronic effects of $B_{2}$-adrenergic agonists on body composition and protein synthesis in the rat. Biosci. Rep. 4:83.

Etherington, D. J., M.A.J. Taylor and E. Dransfield. 1987. Conditioning of meat from different species. Relationship berween tenderizing and the level of cathepsin B, cathepsin L, calpain I, calpain II and beta-glucuronidase. Meat Sci. 20:1.

Forsberg, N. E., A. R. Nassar, R. H. Dalrymple and C. A. Ricks. 1987. Cimaterol reduces cathepsin B activity in sheep skeletal muscle. Fed. Proc. 46:1176 (Abstr. \#5009).

Goll, D. E., R. W. Bray and W. G. Hoekstra. 1963. Ageassociated changes in muscle composition. The isolation and properties of a collagenous residue from bovine muscle. J. Food Sci. 28:503.

Gornall, A. G., C. J. Bordawill and M. M. David. 1949. Determination of serum proteins by means of the biuret reaction. J. Biol. Chem. 177:751

Hamby, P. L., J. R. Stouffer and S. B. Smith. 1986. Muscle metabolism and real-time ultrasound measurement of muscle and subcutaneous adipose tissue growth in lambs fed diets containing a beta-agonist. J. Anim. Sci. 63:1410.

Hill, F. 1966. The solubility of intramuscular collagen in meat animals of various sizes. J. Food Sci. 31:161.

Jones, S. J., E. D. Aberle and M. D. Judge. 1986. Skeletal muscle turnover in broiler and layer chicks. J. Anim. Sci. 62:1576.

Jones, R. W., R. A. Easter, F. K. McKeith, R. H. Dalrymple, H. M. Maddock and P. J. Bechtel. 1985. Effect of the B-adrenergic agonist cimaterol (CL 263,780) on the growth and carcass characteristics of finishing swine. J. Anim. Sci. 61:905.

Kang, C. W., M. L. Sunde and R. W. Swick. 1985. Growth and protein tumover in the skeletal muscle of broiler chicks. Poult. Sci. 64:370.

Kim, Y. S., Y. B. Lee and R. H. Dalrymple. 1987. Effect of the repartitioning agent cimaterol on growth, carcass and skeletal muscle characteristics in lambs. J. Anim. Sci. 65:1392.

Koohmaraie, M., J. E. Schollmeyer and T. R. Dutson. 1986. Effect of low-calcium-requiring calcium-activated factor on myofibrils under varying $\mathrm{pH}$ and temperature conditions. J. Food Sci. 51:28.

Kretchmar, D. H., M. R. Hathaway, R. J. Epley and W. R. Dayton. 1988. Effect of a dietary beta-agonist on calcium-activated proteinase and cathepsin activities in ovine muscle tissue. J. Anim. Sci. 66 (Suppl. 1):148 (Abstr.).

Labraca, C. and Paigen K. 1980. A simple, rapid and sensitive DNA assay procedure. Anal. Biochem. 102: 344.

Lin, R. I. and O. A. Schjeide. 1969. Micro-estimation of RNA by the cupric ion catalyzed orcinol reaction. Anal. Biochem. 27:473.

MacRae, J. C., G. E. Lobley and P. A. Skene. 1986. The effects of the B-adrenergic agonist clenbuterol on the energy expenditure and protein turnover of wether lambs. J. Anim. Sci. 63 (Suppl. 1):453 (Abstr.).

Maruyama, K., M. L. Sunde and R. W. Swick. 1978. Growth and muscle protein tumover in the chick. Biochem. J. 176:573.

McDonald, M. L. and R. W. Swick. 1981. The effect of protein depletion and repletion on muscle-protein turnover in the chick. Biochem. J. 194:811.

Millward, D. J., P. J. Garlick, R.J.C. Stewart, D. O. 
Nnanyelugo and J. C. Waterlow. 1975. Skeletalmuscle growth and protein turnover. Biochem. J. 150: 235.

Millward, D. J., M. P. Sparrow, G. J. Laurent and C. C. Lo. 1978. Factors affecting protein breakdown in muscle. In: H. Segal and D. Doyle (Ed.) Protein Turnover and Lysosome Function. pp 619-644. Academic Press, New York.

Moeller, P. W., P. A. Fields, T. R. Dutson, W. A. Landmann and Z. L. Carpenter. 1976. Effect of high temperature conditioning on subcellular distribution and levels of lysosomal enzymes. J. Food Sci. 41:216.

Ouali, A., N. Garrel, A. Obled, C. Deval and C. Valin. 1987. Comparative action of cathepsins D, B, H, L and of a new cysteine proteinase on rabbit myofibrils. Meat Sci. 19:83.

Reeds, P. J., S. M. Hay, P. M. Dorwood and R. M. Palmer. 1986. Stimulation of muscle growth by clenbuterol: lack of effect on muscle protein biosynthesis. Br. J. Nutr. 56:249.

Shiboko, S., P. Kiovistoinen, C. A. Tratnyek, A. R. Newhall and L. Friedman. 1967. A method for sequential quantitative separation and determination of protein, RNA, DNA, lipid and glycogen from a single rat liver homogenate from a subcellular fraction. Anal. Biochem. 19:514.

Steel, R.G.D. and J. H. Torrie. 1980. Principles and Procedures of Statistics (2nd Ed.). McGraw-Hill Book Co., New York.

Trenkle, A. 1986. Regulation of protein synthesis. In: Proc. Symp. on Food Animal Research. pp 80-91. November 2-4, 1986, Lexington, KY. Intersociety Research Committee.

Wang, S. Y., R. M. O'Connor and D. H. Beerman. 1988. Effect of cimaterol on proteolytic activity and growth in lamb skeletal muscle. Fed. Proc. 47:A847 (Abstr. \#3207).

Watson-Wright, W. M. and M. Wilkinson. 1986. The muscle slice-a new preparation for the characterization of beta-adrenergic agonist binding the fast and slow twitch skeletal muscle. Muscle \& Nerve 9:416.

Wu, J. J., C. L. Kastner, M. C. Hunt, D. H. Kropf and D. M. Allen. 1981. Nutritional effects on beef collagen characteristics and palatability. J. Anim. Sci. 53:1256. 